\title{
TRUST AS A FACTOR IN DETERMINING HOW TO ATTRACT, MOTIVATE AND RETAIN TALENT
}

\author{
NICO MARTINS \\ Department of Industrial Psychology \\ Unisa \\ HARTMUT VON DER OHE \\ Department of Industrial Psychology \\ Unisa
}

\begin{abstract}
The aim of this study was to validate a questionnaire that can be used to determine how employees select the bes company to work for. The second focus was to determine the role of trust in a relationship where employers must attract, motivate and retain employees. The confirmatory factor analysis resulted in 10 dimensions that supported most of the theoretically constructed dimensions. A second-order factor analysis was done and it became clear that there are two second-order factors underlying factor 1, namely leadership and trust. A strong correlation was found between trust and the dimensions of job satisfaction, relationships and leadership.
\end{abstract}

\section{OPSOMMING}

Die doel van die studie was om 'n vraelys te valideer wat gebruik kon word om te bepaal hoe werknemers die beste organisasie om voor te werk kies. Die tweede fokus was om die rol van vertroue te bepaal in ' $n$ vertrouensverhouding waar werkgewers werknemers moet lok, motiveer en behou. ' $n$ Bevestigende faktorontleding het tien faktore tot gevolg gehad wat die meeste van die teoreties opgestelde dimensies ondersteun. 'n Tweede-orde-faktorontleding van faktor een het aangetoon dat die faktor uit twee tweede-orde-faktore, leierskap en vertroue bestaan. ' $n$ Sterk korrelasie het voorgekom tussen vertroue en die dimensies van postevredenheid, verhoudinge en leierskap.

This study examined the factors that are considered by employees when choosing the best company to work for. The second focus of the study was to explore the role of trust in such a relationship. According to Lau and May (1998) management recognises that a productive workforce will provide a global, sustainable competitive advantage for business organisations. As the composition of the workforce continues to change over coming years, companies that offer better benefits and supportive working environments are expected to gain leverage in hiring and retaining valuable people. According to De Beer and Radley (2000) individual potential cannot be optimised unless cultural differences are understood and managed. Kandola and Fullerton (1998) suggest that there is evidence of the benefits for organisations which ensure that they retain all their staff by providing an environment in which their potential is realised.

The inability to value and manage diversity will contribute substantially to declining productivity and profitability in the years ahead. Tom (1971) postulated that Super's theory of occupational choice can also be extended to organisational choice of an individual and may also be a means of implementing an individual's self concept. The relationship between the individual's self concept (perception of self) and the organisational image (individual's perception of the organisation) could be a determinant of organisa tional choice.

Schreuder and Theron (2001) summarise earlier researchers' findings on what influences organisational choice per se as the nature of work, progress, starting salary, opportunity for promotion, intellectual aspects and recognition.

According to Brety, Ash and Dreher (1989) homogeneity also plays a role in organisational choice. Fortune and Hay Consulting's 1988 list of the most admired global companies points to a single best predictor of overall excellence: the ability to attract, motivate and retain talented people (Charlton, 2000, p. 9).

Requests for copies should be addressed to: $N$ Martins, Department of Industrial Psychology, UNISA, Po Box 392, UNISA, 0003.E-mail: martin@unisa.ac.za
According to Charlton (2000, pp. 9 10) the themes or important aspects that need to be taken into account are:

- attracting, developing, motivating and retaining leadership and inculcating team leadership

- the continuing capacity to change

- encouraging diversity while acting globally

- accountability for sustained performance based on relevant performance competencies

- a comprehensive strategic human resource perspective owned by people

Shaw $(1997$, p. 7) argues that trust is a key competitive issue for organisations and plays a critical role in the following organisational responses:

- empowering individuals and teams

- horizontal business processes

- business unit autonomy and power

- cross group collaboration

- alliances and joint ventures

- real time organisational learning

The changing nature of work and the response of organisations to globalisation have emphasised the importance of trust. Current trends in the changing workforce composition and the implementation of the Employment Equity Act in South Africa suggest that the importance of trust is likely to increase over the next few years (Martins, 2000).

According to Peterson and Smith (2000, p. 109) trust affects all relationships, but it plays a larger part in lateral than in hierarchical relationships. In any relationship, events occur that can make a party vulnerable. Researchers such as Charlton (2000), Katzenbach and Smith (1993), Martins (2000), and Shaw (1997) have argued theoretically and empirically about the impact of trust on the various relationships in organisations. The impact of trust appears to be most relevant in organisational elements such as leadership, relationships, conflict, change, communication and diversity management. Researchers have attached various characteristics or components to trust (Charlton, 2000; Katzenbach \& Smith, 1993; McKnight \& Webster, 2001; Peterson \& Smith, 2000): 
- calculative trust salience of trustworthy exchanges for individual benefit

- relational trust an organisation's history and mythology of trustworthy behaviour

- institutional trust an established system of rewards and sanctions corresponding to trustworthy behaviour

- a key characteristic of high performance teams

- trust in leadership as well as the leader's trusting other people to do what needs to be done

- influence of trust in institutions at the societal level on the organisational trust climate, (Trust climate is seen as one of the dimensions of organisational trust)

- a multi dimensional typology at individual, interpersonal and institutional levels

The present study examines trust as one dimension of the factors that employees consider when choosing a company to work for. In this context aspects such as the trust relationship between the immediate manager and subordinates, trust between employees, respect, care and motivation were included. The relationship between trust and other dimensions was also determined.

In the last few years South African organisations have experienced drastic changes, re engineering, downsizing, ferocious global competition and the implementation of various new labour laws. These changes have led to a shift on both sides of the employment contract which is leading to a widening of the trust gap between employees and their employers (Martins, 2000). Employers can only speculate what the impact of the widening trust gap is on attracting and retaining talented workers. According to Pfeiffer (1991) trust is emphasized in the philosophies of renewed organisations.

Various criteria are used to determine the best or most admired companies to work for, for instance:

- pay and benefits, opportunities, job security, pride in work and company, openness and fairness, camaraderie and friendliness (Lau \& May, 1998)

- completing a trust index, receiving supplementary material such as newsletters, employee handbooks and videos (Branch, 1999)

- quality of management, quality of products and services, innovativeness, long term investment value, financial soundness, ability to attract, develop and retain talent, community responsibility, use of corporate assets and globa business acumen (Stein, 2000)

- macrocriteria: financially stable, enjoy success in its markets, enjoys status and reputation, salary/benefits/work environs, recruitment, career opportunities and development, job security/handling corporate change and the human face of the company (Donald, 2000)

The above suggest that various methods are used to determine what factors attract, motivate and help retain talented people. In an attempt to establish what these methods are, research was conducted to determine the factors that attract and retain employees. The changing workforce composition and changing work environment also encouraged the researchers to investigate the role of trust as a factor in attracting and retaining employees.

\section{METHOD}

\section{Participants}

In total, 1984 employees from 42 companies participated in the survey. Fifty five percent of respondents had less than four years of service: the majority $(75,9 \%)$ had been employed for less than 11 years. More than $60 \%(62,6 \%)$ of the population was over the age of 30 with the majority $(36,5 \%)$ falling between the ages of 31 and 45 years. A quarter of the respondents $(24,7 \%)$ were from the ranks of middle management, professionals/specialists $(26,6 \%)$ and general staff $(26,2 \%)$.
Developing the measuring instrument

Deloitte and Touche, Human Capital Corporation sponsored a project to determine the best companies to work for in South Africa. As this was the first project of this nature in South Africa it was decided to first develop a theoretical model. The theoretical model was used to develop dimensions and statements to compile a questionnaire. In order to differentiate the survey from other similar initiatives it was decided to include both employer and employee perceptions and also external market perceptions in the final analysis. This study focuses only on the validation of the employee questionnaire.

The following steps were used to compile the employee perception questionnaire:

- A project team selected aspects that might have an impact on attracting and retaining employees.

- A theoretical model (Dicks, Smith \& Martins, 2001, p. 51) was developed based on work being done in the USA in particular (figure 1).

- Questions were compiled and grouped into dimensions.

- An independent panel of experts from labour and the private sector and academics checked the prepared questionnaire for face validity. Questions and dimensions that did not satisfy the panel were excluded from the questionnaire.

The final questionnaire consists of 101 questions that were grouped into 12 dimensions.

The following dimension were identified:

- diversity

- change

- trust

- management information

- leadership

- rewards and recognition

- policies and procedures

- development and training

- job satisfaction

- change which has occurred

- communication sources

The items (questions) are endorsed in a five point interval scale, the lowest anchor signifying not applicable, the next anchor signifying strongly disagree and the highest strongly agree. The scale ranges from 0 to 4 .

\section{Procedure}

The questionnaire was distributed to interested companies for completion. A covering letter explaining the purpose of the survey was included with the questionnaire. A contact person in each company assisted with the distribution and collection of the questionnaires. The guideline for completion was 50 to 200 randomly selected employees. The respondents were assured that the data would be kept confidential and anonymous.

The overall purpose of this phase was to validate the original theoretical model of attracting and retaining employees (figure 1). The second phase was to determine if there are any correlations between trust and the dimensions of attracting and retaining employees. The business focus was to determine the top companies to work for.

\section{RESULTS}

In the organisational literature and commonly in role based research, factor analysis is frequently used to assess whether instruments measure substantive constructs (Cortina, 1993; Drasgow \& Miller, 1982). Hair, Anderson, Tatham and Black (1995) argue that the analyst has perceived thoughts about the actual structure of the data, based on theoretical support or 
FigURE 1: FrAMEWORK FOR BEST COMPANIES TO WORK FOR

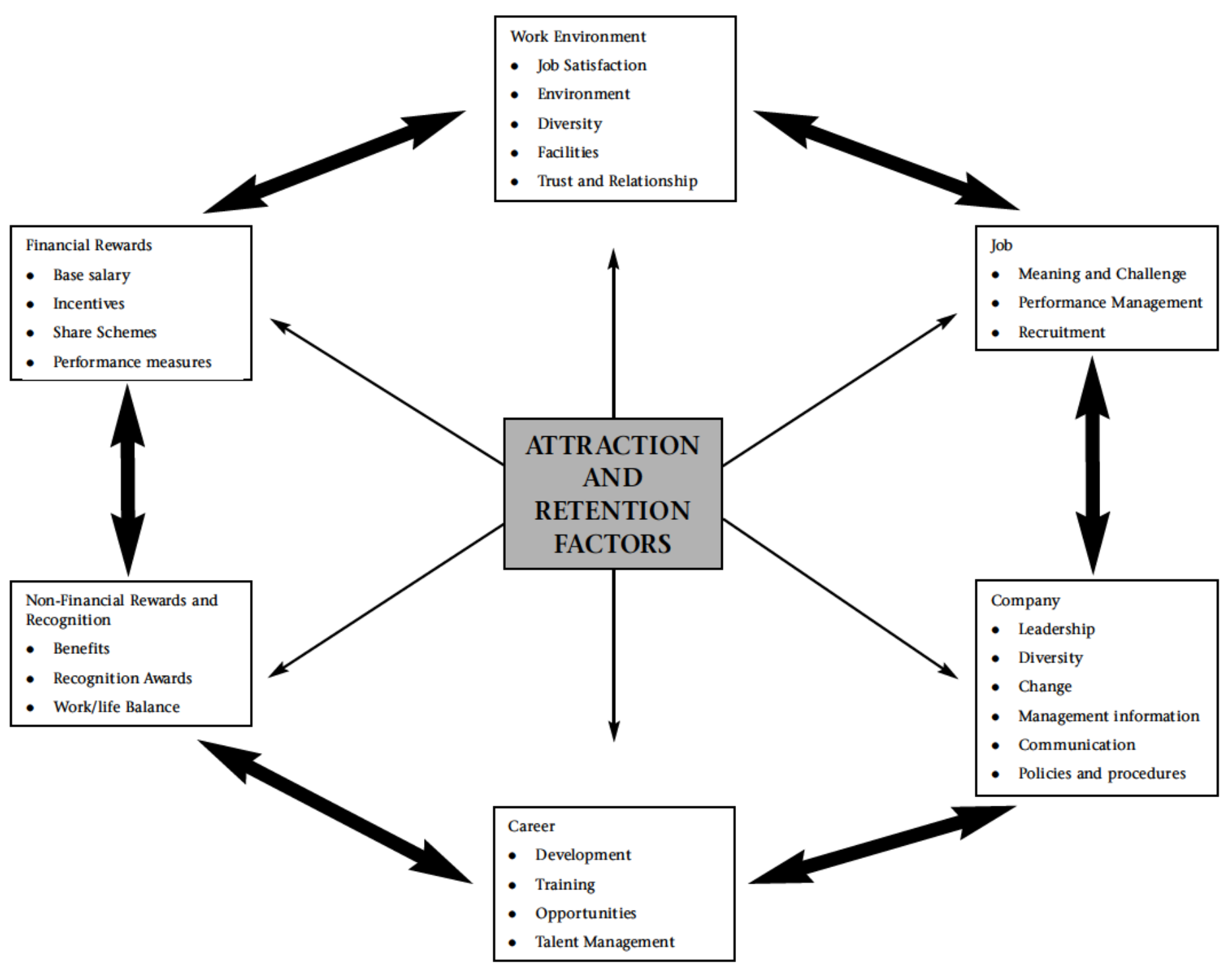

prior research. The analyst may test hypothesis involving issues such as which variables should be grouped together in a factor or the precise number of factors.

In these instances, the analyst requires factor analysis to take a confirmatory approach that is, to assess the degree to which data meets the expected structure of the analyst. With the original factor structure in mind, 10 factors were used as the criteria for the factor analysis. A priori criterion is based on the reasonable criterion of the process applied to construct the theoretically constructed factors. A varimax rotation was used and the 10 extracted factors accounted for $49 \%$ of the variance (table 1). The factor loadings of the items within each sub scale are given in table 2 . The items with their factor loadings are reported and are sorted by dimension and strength of factor loading within dimension. Factor loadings greater than 0,30 were considered to meet the researchers minimum level to be included in a factor. In the assessment of how items load on the 10 factors identified with the varimax rotation, factor 1 has one item that does not meet the 0,3 criterion. All the items of factor 2 meet the 0,3 criterion, while two items of factor 3 do not meet the criterion. One item of both factor 4 and 5 do not meet the criterion. Two items from factors 6 and 7 do not meet the 0,3 criterion. All the items of factors 8 and 9 meet the criterion. The results of the factor analysis indicate that 10 items can be excluded from the measuring instrument.
TABLE 1

TOTAL VARIANCE EXPLAINED

\begin{tabular}{lcccccc}
\hline & \multicolumn{5}{c}{ Initial Eigenvalues } & \multicolumn{3}{c}{ Rotation Sums of Squared Loadings } \\
Factor & Total & $\begin{array}{c}\text { \% of } \\
\text { variance }\end{array}$ & $\begin{array}{c}\text { Cummulative } \\
\%\end{array}$ & Total & $\begin{array}{c}\text { \% of } \\
\text { variance }\end{array}$ & $\begin{array}{c}\text { Cummulative } \\
\%\end{array}$ \\
\hline 1 & 29,995 & 30,607 & 30,607 & 8,575 & 8,750 & 8,750 \\
2 & 3,597 & 3,670 & 4,277 & 5,562 & 5,676 & 14,426 \\
3 & 2,599 & 2,652 & 36,929 & 4,114 & 4,198 & 18,624 \\
4 & 2,145 & 2,189 & 39,118 & 4,056 & 4,139 & 22,763 \\
5 & 1,951 & 1,990 & 41,108 & 3,961 & 4,042 & 26,804 \\
6 & 1,865 & 1,903 & 43,011 & 3,960 & 4,040 & 30,845 \\
7 & 1,708 & 1,743 & 44,754 & 3,404 & 3,473 & 34,318 \\
8 & 1,651 & 1,685 & 46,439 & 3,156 & 3,221 & 37,538 \\
9 & 1,464 & 1,494 & 47,933 & 3,122 & 3,186 & 40,724 \\
10 & 1,421 & 1,450 & 49,383 & 2,933 & 2,993 & 43,717 \\
11 & 1,318 & 1,345 & 50,728 & & & \\
12 & 1,310 & 1,336 & 52,064 & & & \\
13 & 1,266 & 1,292 & 53,356 & & & \\
14 & 1,170 & 1,194 & 54,550 & & & \\
\hline & & & & & & \\
\hline
\end{tabular}


TABLE 2

\section{ROTATED FACTOR MATRIX}

\begin{tabular}{|c|c|c|c|c|c|c|c|c|c|c|}
\hline & $\begin{array}{c}\text { FACTOR } \\
1\end{array}$ & 2 & 3 & 4 & 5 & 6 & 7 & 8 & 9 & 10 \\
\hline My immediate manager enjoys my trust. & 0,701 & & & & & & & & & \\
\hline My immediate manager trusts me. & 0,695 & & & & & & & & & \\
\hline With my immediate manager my opinions count. & 0,667 & & & & & & & & & \\
\hline My immediate manager cares about me as a person. & 0,661 & & & & & & & & & \\
\hline $\begin{array}{l}\text { My immediate manager tries to remove obstacles that occur in the } \\
\text { work environment. }\end{array}$ & 0,637 & & & & & & & & & \\
\hline My immediate manager gives clear instructions. & 0,611 & & & & & & & & & \\
\hline My immediate manager sets achievable goals for subordinates. & 0,597 & & & & & & & & & \\
\hline $\begin{array}{l}\text { My manager involves me in decisions that affect my job or } \\
\text { work environment. }\end{array}$ & 0,561 & & & & & & & & & \\
\hline My immediate manager allocates resources adequately. & 0,544 & & & & & & & & & \\
\hline My manager assists me to develop to my full potential. & 0,536 & & & & & & & & & \\
\hline I feel free to approach management at any time. & 0,459 & & & & & & & & & \\
\hline In the last two weeks I have received praise for good work. & 0,447 & & & & & & & & & \\
\hline Within my department we trust each other. & 0,442 & & & & & & & & & \\
\hline Within my department we motivate and support each other. & 0,393 & & & & & & & & & \\
\hline I have all in place that I need to do my job. & 0,392 & & & & & & & & & \\
\hline I have been encouraged to become involved and committed to change. & 0,362 & & & & & & & & & \\
\hline People in my department respect each other. & 0,344 & & & & & & & & & \\
\hline In the last six months I have been spoken to about my prospects. & 0,326 & & & & & & & & & \\
\hline The people I work with in the organisation are unpleasant. & 0,228 & & & & & & & & & \\
\hline Appointment of middle management. & 0,644 & & & & & & & & & \\
\hline Appointment of top management. & 0,616 & & & & & & & & & \\
\hline Appointment of supervisors. & 0,575 & & & & & & & & & \\
\hline Re-structuring of the organisation. & 0,483 & & & & & & & & & \\
\hline The implementation of gender equality as part of affirmative action. & 0,432 & & & & & & & & & \\
\hline Change to a total package approach to pay. & 0,428 & & & & & & & & & \\
\hline Granting of more decision-making power to lower organisation levels. & 0,415 & & & & & & & & & \\
\hline Re-organising of technical processes and jobs. & 0,410 & & & & & & & & & \\
\hline The offering of severance packages. & 0,402 & & & & & & & & & \\
\hline Employment Equity initiatives. & 0,396 & & & & & & & & & \\
\hline Re-linking or re-grouping to another Division/Business Unit. & 0,396 & & & & & & & & & \\
\hline The implementation of disability equality as part of affirmative action. & 0,376 & & & & & & & & & \\
\hline Downsizing. & 0,322 & & & & & & & & & \\
\hline I am proud to tell my friends I work for this organisation. & & 0,645 & & & & & & & & \\
\hline I would encourage my friends to join this organisation. & & 0,591 & & & & & & & & \\
\hline I believe my work is important. & & 0,583 & & & & & & & & \\
\hline I find my work interesting and challenging. & & 0,569 & & & & & & & & \\
\hline $\begin{array}{l}\text { I feel that most people in my workgroup intend to continue working } \\
\text { for the organisation in the future. }\end{array}$ & & 0,455 & & & & & & & & \\
\hline
\end{tabular}


Everyday I have the opportunity to do what I am best at. $\quad 0,396$

I feel negative about my future in the organisation. $\quad 0,332$

My organisation would appoint someone who is HIV positive. $\quad 0,230$

I don't have any friends amongst those people with whom I work. $\quad 0,136$

$\begin{array}{ll}\text { My organisation recognises and manages the impact of change on employees. } & 0,680\end{array}$

$\begin{array}{ll}\text { Change in my organisation is a well-planned process. } & 0,610\end{array}$

$\begin{array}{ll}\text { My manager recognises the impact of change on me. } & 0,494\end{array}$

In my organisation managers do their job to ensure the success of change. $\quad 0,454$

My organisation assesses managers on managing diversity as part of their $\quad 0,366$

performance appraisal.

Managers in my organisation are trained to act as mentors.

0,315

Timeous and accurate information systems enable employees to act $\quad 0,304$ before the time rather than too late.

White male employees feel threatened by the Employment Equity process in my organisation.

Recruitment policies and procedures are fair to all in their application.

Selection policies and procedures are fair to all in their application.

Job grading policies and procedures are fair to all in their application.

Terms and conditions of service policies and procedures are fair to all

in their application.

Disciplinary procedures policies and procedures are fair to all in

Grievance procedures policies and procedures are fair to all in their application.

My organisation has criteria for selection that are open to all.

Performance and evaluation systems policies and procedures are fair to 
Employees are informed about what other departments are doing.

People in this organisation are willing to go the extra mile when needed.

The people I work with are committed to quality work.

The level of my pay package is influenced by my performance.

A second order factor analysis was conducted for factor 1 . The results and eigenvalues show two factors above the 1,0 eigenvalue (table 3 ). The scree plot also indicated only two factors. A correlation analysis to determine the correlation between the dimensions of trust and the other dimensions is displayed in table 4. Trust correlates the highest with the dimensions of job satisfaction and leadership.

TABLE 3

\section{SECOND ORDER FACTOR ANALYSIS OF FACTOR 1}

\begin{tabular}{cccc}
\hline No & $\begin{array}{c}\text { Eigenvalues } \\
\text { percentage }\end{array}$ & $\begin{array}{c}\text { Individual } \\
\text { percentage }\end{array}$ & Cumulative \\
\hline 1 & 6,184157 & 34,36 & 34,36 \\
2 & 3,295340 & 18,31 & 52,66 \\
3 & 0,991875 & 5,51 & 58,17 \\
4 & 0,961402 & 5,34 & 63,52 \\
\hline
\end{tabular}

\section{Conceptual naming of factors}

Conceptual naming of the 10 factors produced the names as displayed in tables 4 and 5. Each factor will be discussed briefly.

\section{Leadership/Trust}

In the preliminary model trust and leadership were seen as two separate dimensions. The factor analysis revealed a close relationship between leadership and trust as determined by the results of the second order factor analysis. This supports researchers such as Charlton (2000), Katzenbach and Smith
(1993) and Martins (2000), who argue that trust influences leadership. Furnham and Gunter (1993) identified trust as one of the eight dimensions of the universe of psychological perceptions.

\section{TABLE 4}

CORRELATION MATRIX

\begin{tabular}{lc}
\hline Dimensions & Trust \\
\hline Change occurred & 0,493927 \\
Job satisfaction & 0,622442 \\
Management of change & 0,509762 \\
Policies and procedures & 0,510950 \\
Management communication & 0,433401 \\
Relationships & 0,644282 \\
Rewards and recognition & 0,387598 \\
Development and training & 0,530231 \\
Diversity & 0,512811 \\
Leadership & 0,751110 \\
\hline
\end{tabular}

\section{Change occurred}

The factor change, postulated in the empirical research, supports the preliminary factor to a large extent. Only one statement was not included in the final factor (table 5). According to Charlton 
(2000) the continuing capacity for an organisation to change has an impact on employees' decisions to remain with an organisation.

\section{Job satisfaction}

This factor retained eight of the original nine statements. Sparrow (2001) sees job satisfaction as an important part of the psychological contract between the employee and the employer.

\section{Management of change}

Only one statement was excluded from the original factor. This factor focuses on the impact of change on individuals and the organisation. Various researchers have included the concept of change in organisational assessments, for instance Dastmalchin, Blyton and Adamson (1991) (in Furnham \& Gunter, 1993 and Denison, 2001)

\section{Policies and procedures}

The factor analysis identified 10 policies and procedures which are mostly in line with the original factor. Only one statement loaded too low on the item analysis to be included. This factor is not typically included in organisational surveys that focus on climate/culture. However, the number of new Acts that have been implemented in South Africa have forced organisations to update, change and improve their policies and procedures and to align themselves with the latest legislation. These new policies and procedures have an effect on the organisational environment and on internal external relationships. According to Sparrow et al. (2001), climate instruments tap into the practices and procedures.

\section{Management communication}

The original 10 statements were retained after the factor analysis. Communication is seen as one of the important components of most organisational assessments (Furnham \& Gunter, 1993).

\section{Relationships}

Table 5 shows that this dimension differs from the original theoretical conceptual factor. The newly formed factor focuses on the relationship between employees and their immediate managers and on the relationships between departments. Kays and De Cottis (1991) (in Furnham \& Gunter, 1993, p. 152) summarised the various psychological climate dimensions and found that recognition is labelled by many researchers as the summary dimension for reward punishment relationships.

\section{Rewards and recognition}

The original five statements were maintained after the factor analysis. Rewards and recognition are included in most climate or organisational surveys to determine employees satisfaction/dissatisfaction with rewards and recognition (Furnham \& Gunter, 1993).

\section{Development and training}

This factor grouped all aspects relating to the development and training of employees together. Six statements were grouped together. The concepts of jobs/skills match, support and empowerment are all seen by researchers as dimensions that relate to the theme of development and training (Charlton, 2000; Kays \& De Cottis (in Furnham \& Gunter, 1993); Kraut, 1996).

Diversity

Only five of the original 11 statements were retained. One statement was excluded due to a low loading on the item analysis. The theme of diversity was not included in most original organisational assessments. But in view of the changing South African environment it is now included.
Earlier diagnostic surveys focused on dimensions such as fairness and diversity assessment (Furhnam \& Gunter, 1993; Kraut, 1996).

Item and reliability analysis

Table 6 shows the Cronbach's Alpha for the 10 dimensions. The alpha coefficients portray highly satisfactory results with coefficients ranging between 0,7961 and 0,9320 . All factors except factor 1 are below 0,8 which can be regarded as good (very reliable).

TABLE 5

QUALITATIVE ANALYSIS OF FACTORS

\begin{tabular}{|c|c|c|c|}
\hline $\begin{array}{l}\text { Items after } \\
\text { factor and } \\
\text { item analysis }\end{array}$ & Old dimension(s) & $\begin{array}{l}\text { New dimension(s) } \\
\text { after factor } \\
\text { analysis and } \\
\text { item analysis }\end{array}$ & $\begin{array}{l}\text { Results of second } \\
\text { order factor } \\
\text { analysis }\end{array}$ \\
\hline $\begin{array}{l}\text { Factor } 1 \\
21,20,48,51,34, \\
35,31,5,33,67,47 \\
37,22,46,32,19 \\
50,69,[45]\end{array}$ & $\begin{array}{l}\text { Trust (3), } \\
\text { relationship (5), } \\
\text { leadership (5), } \\
\text { development and } \\
\text { training (2), } \\
\text { rewards and } \\
\text { recognition (1), } \\
\text { diversity (1) and } \\
\text { change (1) }\end{array}$ & $\begin{array}{l}\text { Leadership/trust } \\
\text { (18) }\end{array}$ & $\begin{array}{l}\text { Sub Factor 1: } \\
\text { Leadership } \\
67,33,31,34,35,5 \text {, } \\
48,69,37,32,7,19 \\
\text { Sub Factor } 2 \text { : } \\
\text { Trust } \\
50,46,22,20,21,51\end{array}$ \\
\hline $\begin{array}{l}\text { Factor } 2 \\
79,80,81,82,83 \\
84,85,86,87,88, \\
89,90,[91]\end{array}$ & $\begin{array}{l}\text { Change occurred } \\
\text { (13) }\end{array}$ & $\begin{array}{l}\text { Change occurred } \\
\text { (12) }\end{array}$ & \\
\hline $\begin{array}{l}\text { Factor } 3 \\
70,71,72,73,74,75 \\
76,77,78,[42]\end{array}$ & $\begin{array}{l}\text { Job satisfaction } \\
\text { (9) } \\
\text { and relationships } \\
\text { (1) }\end{array}$ & $\begin{array}{l}\text { Job satisfaction } \\
\text { (8) }\end{array}$ & \\
\hline $\begin{array}{l}\text { Factor } 4 \\
17,16,18,15,6,68 \\
30,[14]\end{array}$ & $\begin{array}{l}\text { Change (4), } \\
\text { diversity (2), } \\
\text { management } \\
\text { information (1), } \\
\text { development and } \\
\text { training (1) }\end{array}$ & $\begin{array}{l}\text { Management of } \\
\text { change (7) }\end{array}$ & \\
\hline $\begin{array}{l}\text { Factor } 5 \\
52,53,54,55,56, \\
57,59,60,61, \\
{[62], 4}\end{array}$ & $\begin{array}{l}\text { Policies and } \\
\text { procedures (10), } \\
\text { diversity (1) }\end{array}$ & $\begin{array}{l}\text { Policies and } \\
\text { procedures (10) }\end{array}$ & \\
\hline $\begin{array}{l}\text { Factor } 6 \\
92,93,94,95,96 \\
97,98,99,100,101\end{array}$ & $\begin{array}{l}\text { Management } \\
\text { communication } \\
\text { (10) }\end{array}$ & $\begin{array}{l}\text { Management } \\
\text { communication } \\
\text { (10) }\end{array}$ & \\
\hline $\begin{array}{l}\text { Factor } 7 \\
27,26,24,23,36, \\
44,28,43,25,49, \\
{[29]}\end{array}$ & $\begin{array}{l}\text { Trust (3), } \\
\text { management } \\
\text { information (4), } \\
\text { leadership (1), } \\
\text { relationships (3) }\end{array}$ & $\begin{array}{l}\text { Relationships } \\
\text { (10) }\end{array}$ & \\
\hline $\begin{array}{l}\text { Factor } 8 \\
38,39,40,41\end{array}$ & $\begin{array}{l}\text { Rewards and } \\
\text { recognition (4) }\end{array}$ & $\begin{array}{l}\text { Rewards and } \\
\text { recognition (4) }\end{array}$ & \\
\hline $\begin{array}{l}\text { Factor } 9 \\
64,58,63,65 \\
66,7\end{array}$ & $\begin{array}{l}\text { Development } \\
\text { and training (4), } \\
\text { policies and } \\
\text { procedures (1) } \\
\text { and diversity (1) }\end{array}$ & $\begin{array}{l}\text { Development } \\
\text { and training (6) }\end{array}$ & \\
\hline $\begin{array}{l}\text { Factor } 10 \\
12,11,10,9,[8], 13\end{array}$ & Diversity (11) & Diversity (5) & \\
\hline
\end{tabular}

Notes:

1. [ ] refer to items that loaded low on the item analysis

2. Brackets ( ) refer to the number of items per dimension 
TABLE 6

RESULTS OF THE ITEM ANALYSIS

\begin{tabular}{|c|c|c|c|c|}
\hline \multirow[b]{2}{*}{ Factors } & \multicolumn{2}{|c|}{ All Items } & \multicolumn{2}{|c|}{ Only items that correlate } \\
\hline & $\begin{array}{c}\text { No of } \\
\text { Questions }\end{array}$ & $\begin{array}{l}\text { Cronbach's } \\
\text { alpha }\end{array}$ & $\begin{array}{c}\text { No of } \\
\text { Questions }\end{array}$ & $\begin{array}{c}\text { Cronbach's } \\
\text { alpha }\end{array}$ \\
\hline 1 & 19 & 0,9304 & 18 & 0,9320 \\
\hline 2 & 13 & 0,9043 & 12 & 0,9095 \\
\hline 3 & 10 & 0,8491 & 8 & 0,8637 \\
\hline 4 & 8 & 0,8163 & 7 & 0,8319 \\
\hline 5 & 11 & 0,9180 & 10 & 0,9185 \\
\hline 6 & 10 & 0,8361 & 10 & 0,8361 \\
\hline 7 & 11 & 0,8741 & 10 & 0,8851 \\
\hline 8 & 4 & 0,8394 & 4 & 0,8394 \\
\hline 9 & 6 & 0,7961 & 6 & 0,7961 \\
\hline 10 & 6 & 0,8727 & 5 & 0,8743 \\
\hline
\end{tabular}

\section{DISCUSSION}

The results obtained in the present study supported most of the theoretically constructed dimensions. The confirmatory factor analysis resulted in 10 dimensions that were, however, grouped somewhat differently. The main changes in the grouping of the items occurred for factors 1 and 7.

The grouping of the remaining eight dimensions generally corresponded with the original theoretically constructed dimensions. The factors yielded reliabilities ranging from 0,796 to 0,932 . The 10 dimensions that emerged were identified as dimension 1: leadership/trust, dimension 2: change occurred, dimension 3: job satisfaction, dimension 4: management of change, dimension 5: policies and procedures, dimension 6: management communication, dimension 7: relationships, dimension 8: rewards and recognition, dimension 9: development and training and dimension 10: diversity.

It is clear from the second order factor analysis that was done on the first factor, that there are two second order factors underlying factor 1 , namely leadership and trust. Both these second order factors loaded positively on the scree plot and the eigenvalues are above 1 . The second order factor of trust focuses mainly on aspects such as manager/subordinate trust relationships, departmental/sectional trust relationships, departmental motivation, respect and care. This supports some of the components of trust as identified by other researchers working on the concept and characteristics of trust (Charlton, 2000; Katzenbach \& Smith, 1993; McKnight \& Webster, 2001).

A correlation analysis between trust and the other dimensions indicates high relationships between job satisfaction, relationships and leadership. The present study thus generally confirms research which indicates that trust is created by leadership which influences relationships and job satisfaction.

As far as the theoretical model is concerned, it was found that all the factors do not correlate equally and that there is a stronger focus on some dimensions (leadership, change occurred, policies and procedures, management com munication and relationships) than on others (rewards and recognition, diversity and development and training). The implication of this is that the original framework (figure 1) needs to be adapted to the present research. Structural equation modelling could be considered to confirm and/or create a new model.

In conclusion, the present study opens up new research possibilities, for instance understanding the criteria that influence an individual's attraction to an organisation and how to retain talent. The present study emphasises the importance of leadership in attracting and retaining talent. The concept of trust needs to be expanded to include more items that focus on aspects such as loyalty, integrity, congruence between individual and organisational values and the role of organisational culture in retaining and attracting talented people.

\section{REFERENCES}

Branch, S. (1999). The 100 best companies to work for in America. Fortune, January 11, 5872.

Brety, R.D., Ash, R.A. \& Dreher, G.F. (1989). Do people make the place? An examination of the attraction selection attention hypothesis. Personnel Psychology, 42 (3), 561581.

Charlton, G. (2000). Human habits of highly effective organisations. Pretoria: Van Schaik.

Cortina, J.M. (1993). What is coefficient alpha? An examination of theory and applications. Journal of Applied Psychology, 78, 98104.

De Beer, J.J. \& Radley, J.H. (2000). A case for managing diversity. Hatfield: Enya Press Office.

Denison, D. (2001). Organisational culture: Can it be a key lever for driving organisational change. In C.L. Cooper; S. Cartwright \& P.C. Earley (Eds.). International handbook of organisational culture and climate. New York: John Wiley.

Dicks, H., Smith, N. \& Martins, N. (2001). SA's Best Companies to work for survey. HR Future, 1 (6), 4851.

Donald, P.C. (2000). The best companies to work for in SA. Cape Town: Zebra.

Drasgow, F. \& Miller, H.E. (1982). Psychiatric and substantive issues in scale construction and validation. Journal of Applied Psychology, 67, 268279.

Furnham, A. \& Gunter, B. (1993). Corporate assessment. Auditing a company's personality. London: Routledge.

Hair, J.F. jr., Anderson, R.E., Tatham, R.L. \& Black, W.C. (1995). Multivariate data analysis. (4th Ed.). Englewood Cliffs, NJ: Prentice Hall.

Katzenbach, J.R. \& Smith, D.K. (1993). The wisdom of teams. Boston, MA: Harvard Business School.

Kraut, A.I. (1996). Organisational surveys: Tools for assessment and change. San Francisco: Jossey Bass.

Kandola, R. \& Fullerton, J. (1998). Diversity in action: Managing the mosaic. London: The Cromwell Press.

Lau, R.S.M. \& May, B.E. (1998). A win win paradigm for quality of work life and business performance. Human Resource Development Quarterly, 9 (3), 211226.

Martins, N. (2000). Developing a trust model for assisting management during change. Journal of Industrial Psychology, (3), 2738.

McKnight, D.H. \& Webster, J. (2001). Collaborative insight of privacy invasion? Trust climate as a lens for understanding acceptance of awareness systems. In C.L.Cooper, S. Cartwright \& P.C. Earley (Eds.). International handbook of organizational culture and climate. New York: John Wiley.

Peterson, M.F. \& Smith, P.B. (2000). Sources of meaning, organisations and culture: Making sense of organisational events. In N.M. Ashkanasy, C.P.M. Wilderom \& M.F. Peterson (Eds.). Handbook of organizational culture and climate. London: Sage. 
Pfeiffer, J.W. (1991). Theories and Models in applied behavioural science. (Vol. 4). San Diego, CA: Pfeiffer.

Schreuder, A.M.G. \& Theron, A.L. (2001). Careers: An organizational perspective. Landsdowne: Juta.

Sparrow, P.R. (2001). Developing diagnostics for high performance organizational cultures. In C.L. Cooper, S. Cartwright \& P.C. Earley (Eds.). International handbook of organisational culture and climate. New York: John Wiley.
Shaw, R.B. (1997). Trust in the balance. San Francisco: Jossey Bass.

Stein, N. (2000). The world's most admired companies. Fortune, October 2, 6368.

Tom, V.T. (1971). The role of personality and organizational images in the recruiting process. Organizational Behaviour and Human Performance, 6 (5), 573592. 